\title{
Identification of Sand Flies (Diptera: Psychodidae) Collected from Cutaneous Leishmaniasis Endemic Focus in the Ho Municipality, Ghana
}

\author{
Edna Dzifa Doe ${ }^{1,2^{*}}$, Godwin Kwakye-Nuako ${ }^{1}$, Seth Offei Addo ${ }^{3}$, Alexander Egyir-Yawson ${ }^{1}$ \\ ${ }^{1}$ Department of Biomedical Sciences, School of Allied Health Sciences, University of Cape Coast, Ghana. \\ ${ }^{2}$ Cellular and Clinical Research Centre, Radiological and Medical Sciences Research Institute, GAEC, Ghana. \\ ${ }^{3}$ Noguchi Memorial Institute for Medical Research, Parasitology Department, University of Ghana, Legon \\ * Corresponding author email: dzidey@yahoo.com
}

Received: 15 June 2020 / Accepted: 20 August 2020 / Published: 04 September 2020

\begin{abstract}
Leishmaniasis, is a vector-borne disease transmitted to humans through the bite of infected female sand flies. Active and continuous monitoring of the sand fly is an important aspect of disease control. Thus, the correct identification of its vectors is paramount in this regard. Objective: The study was conducted to morphologically and molecularly identify female sand fly species in a cutaneous leishmaniasis endemic focus collected in three villages in the Ho Municipality of the Volta region. CDC light traps and sticky paper traps was used for the collection of the sand flies. The morphologically identified sand flies was molecularly confirmed by running PCR with the mitochondrial cytochrome c oxidase gene subunit I (COI) primers and DNA sequenced. A total of 537 sand flies was collected, made up of 363 females and 174 males. Eleven different species of sand flies was morphologically identified - one Phlebotomus species and ten Sergentomyia species. The PCR amplified products showed bands of molecular weights 658 base pairs for the primers. The molecular identification using the 658bp fragment of the (COI) gene was congruent with the morphological identification.
\end{abstract}

Keywords: morphological, molecular identification, cytochrome c oxidase gene subunit I

\section{Introduction}

Leishmaniasis is a parasitic disease, presented in three forms including cutaneous (CL), mucocutaneous (MCL), and visceral (VL). CL is the most common and self-limiting depending on the type of Leishmania species causing the disease. The Leishmania parasite is transmitted by infected female sand fly species. These sand flies are small (body length $<3 \mathrm{~mm}$ ) hematophagous insects and are the major cause of public health problem worldwide [1]. There are approximately 800 species of sand flies recorded in five major genera; Pblebotomus and Sergentomyia in the Old World, and Lutzomyia, Brumptomyia and Warileya in the New World [2]. It is evident that proper identification of sand flies in leishmaniasis endemic areas can help assess the risk of spread of the disease [3]. This identification is important for implementing disease control strategy and as such, vector-targeted studies are necessary from the time when the vector has the ability to transmit infectious diseases to humans [4]. Thus, the identification of sand flies by taxonomy is based on morphological features such as cibarium, pharynx, spermatheca of females and terminal genitalia of males [5,6]. This requires careful preparation of insect specimens after a field catch and a high degree of expertise [7]. Thus, to overcome the technical limitations associated with morphological identification, in the last two decades molecular approaches have been increasingly employed to explore the taxonomy and phylogeny in insect vectors including sand flies [8-11]. These molecular identification techniques which use standard 
Identification of Sand Flies (Diptera: Psychodidae) Collected from Cutaneous Leishmaniasis Endemic Focus in the Ho Municipality, Ghana

mitochondrial markers have become the popular approach. For instance, the use of cytochrome c oxidase subunit I (COI) gene [12]. Moreover, the use of ribosomal RNA (rRNA) gene architecture and the highly conserved sequences of certain domains of the gene [13] is another approach.

The aim of this study is to use the approach of COI primers to confirm collected sand flies from three endemic villages in the Ho Municipality of the Volta region of Ghana molecularly, after they have been morphologically identified using taxonomic keys.

\section{Research Methodology}

\subsection{Study Area}

The Ho town doubles as the capital of the Municipality and the Regional Capital of the Volta Region (Figure 1). Its total land area is 2,361 square kilometres. It lies between latitudes $6^{\circ} 36^{\prime} 43^{\prime \prime} \mathrm{N}$ and longitude $0^{\circ} 28^{\prime} 13^{\prime \prime} \mathrm{E}$ and the elevation of the villages is $150 \mathrm{~m} / 490 \mathrm{ft}$ above sea level. The Municipality is a moist semi-deciduous forest zone with villages dotted around. The vegetation of the Municipality is mainly forest and forest savannah. The population of the Municipality according to 2010 population and housing census stands at 177,281 with 83,819 males and 93,462 females as stated by the Ghana Statistical Services Report [14]. The study was carried out in three villages namely Lume Atsiame $\left(6.619918^{\circ} \mathrm{N}, 0.464762^{\circ} \mathrm{E}\right)$, Dodome Dogblome $\left(6.760774^{\circ} \mathrm{N}, 0.51546^{\circ} \mathrm{E}\right)$ and Dodome Awuiasu $\left(6.767553^{\circ} \mathrm{N}, 0.514789^{\circ} \mathrm{E}\right)$. The major economic activities of the population are agriculture, animal farming and trading.

\section{$2.2 \quad$ Ethic Issue}

Ethical clearance was obtained from the University of Cape Coast Institutional Review Board (UCCIRB/CHAS/2017/32). The leaders of the endemic communities and family heads were engaged and consented to this investigation before setting the traps for the sand fly collection around the residence.

\subsection{Sand fly collection}

The collection of sand fly was carried out every day in November and December 2017, January, February, March, April, May, June and August 2018. Siting of the CDC light and sticky traps were randomly selected for sand fly collections in the three endemic areas in the Ho Municipality (Figure 1). The selected communities represent areas in the Municipality where cases of CL had been reported $[15,16]$. A total of four (4) CDC light traps and 20 sticky traps were set from dusk to dawn (approximately 12hr) each day for the collection of flies (Figure 2). The collected sand flies by the CDC light traps were freeze-killed at $-20^{\circ} \mathrm{C}$ and sorted out into labelled $1.5 \mathrm{ml}$ eppendorf tubes containing silica gel for dry preservation. However, the collected sand flies by the sticky traps were preserved in $70 \%$ ethanol. The tubes were secured in sealed sample collection bags and transported to the entomology laboratory for morphological identification.

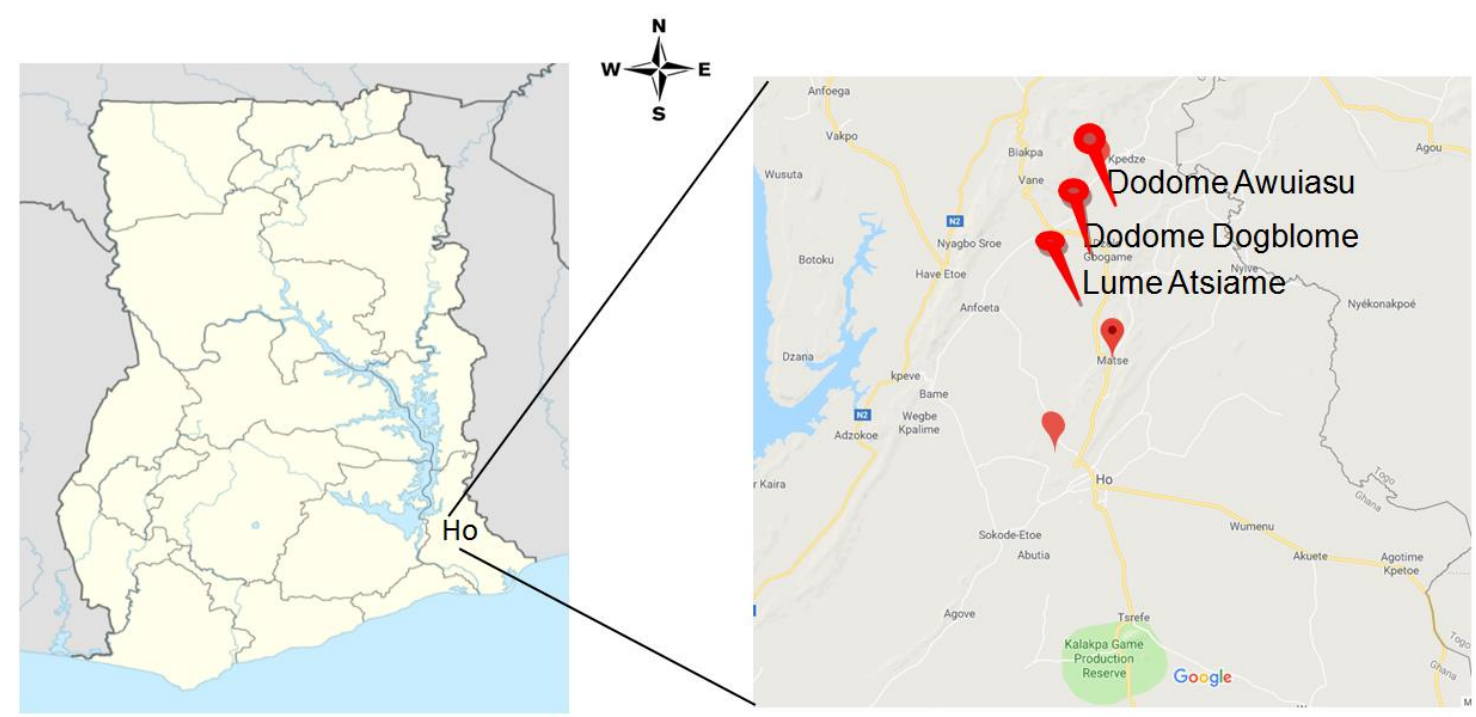

Figure 1: Map of Ghana showing the study areas. 

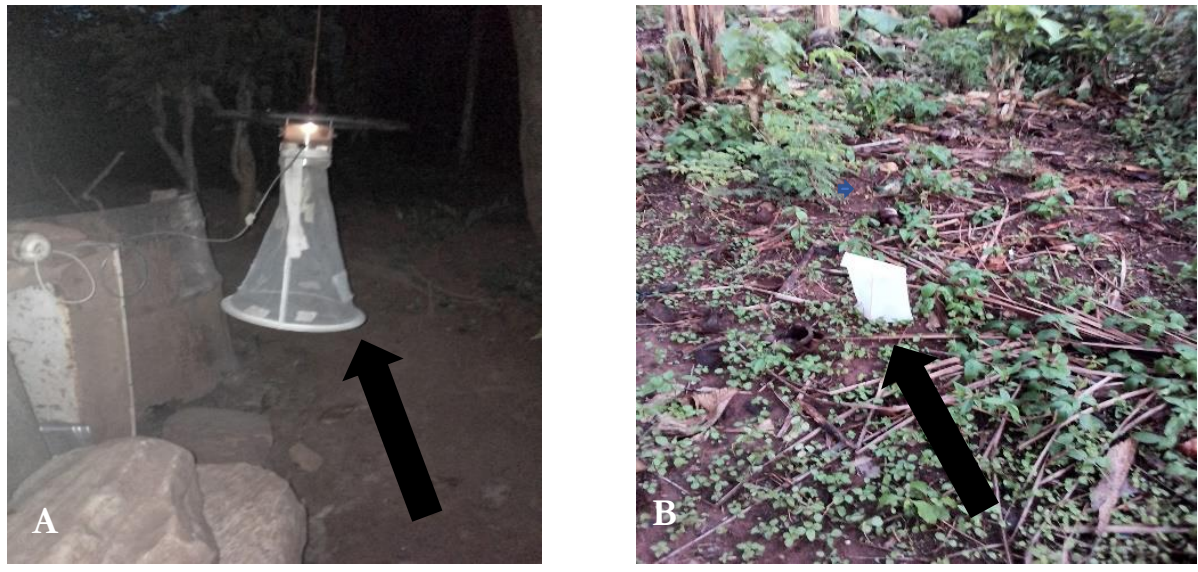

Figure 2: $[A] C D C$ light trap in use and $[B]$ paper sticky trap in use

\subsection{Sand fly dissection and morphological identification}

All sand flies collected were separated into either male or female on the basis of morphology of their reproductive organ observed under a stereomicroscope (Olympus SZ60). Each female sand fly was dissected by first removing the head and last three abdominal segments with a pair of dissecting pins. The head and the last three abdominal segments were placed in a labelled 0.2 $\mathrm{ml}$ sterile micro tube containing 2 drops of clearing medium (chloral hydrate and phenol) for about 48 hours. The thorax and the upper abdominal segment were kept in another $0.2 \mathrm{ml}$ sterile micro tube with the same labelling as that for the head and last three abdominal segments. After the clearing process, the head and last three abdominal segments were placed on a glass slide and a drop of mounting medium (8 $\mathrm{g}$ Arabic gum, $70 \mathrm{~g}$ chloral hydrate, $10 \mathrm{ml}$ distilled water, $5 \mathrm{ml}$ glycerine and $3 \mathrm{ml}$ glacial acetic) was added. Making sure the head was placed with mouthparts facing upward and last abdominal segments in a lateral position, a glass coverslip was used to cover the sample. The slide with the fixed sand fly was allowed to clear and dried using Slide Warmer Model XH-2001 at about $55-60^{\circ} \mathrm{C}$ for about 2 weeks and then observed under an optical microscope for species identification.

Sand flies were identified and grouped into species using taxonomic keys [5]. Morphological features used in the identification of species included the presence of cibarium, cibarial teeth, pharynx and spermatheca. An Olympus BH-2 stereomicroscope with mounted camera connected to a monitor utilizing software was used to capture images of the features of identification interests of the different species. In the identification process, three main features were considered; the cibarium, pharynx and spermatheca. The cibarium is a structure that lies between the pharynx and the proboscis in the head. Present in the cibarium are cibarial teeth which are unique for various species. The pharynx also located in the head and usually a bottle or lamp-glass shaped is a posterior continuation of the cibarium consisting of a dorsal and ventral plate. The spermatheca, found in only the females varies in size and shape for different species. Phlebotomus species have a cibarium which lacks cibarial teeth and a pigmented patch whereas Sergentomyia species have both the cibarial teeth and pigment patch present.

\subsection{DNA extraction}

DNA was extracted from each sand fly using the potassium acetate extraction method as described by Aransay et al., [17] with slight modifications. The individual sand fly was grinded with disposable pestle in $1.5 \mathrm{~mL}$ labelled tubes. One hundred and fifty microliters $(150 \mu \mathrm{L})$ of extraction buffer, which was made up of $1 \%$ sodium dodecyl sulphate [SDS], $25 \mathrm{mM} \mathrm{NaCl}$ and $25 \mathrm{mM}$ EDTA was added, and tubes were placed in a water bath at $65^{\circ} \mathrm{C}$ for 30 minutes. Following the addition of $100 \mu \mathrm{L}$ of $3 \mathrm{M}$ potassium acetate ( $\mathrm{pH}$ 7.2), the homogenates were incubated on ice for 30 minutes and then centrifuged for 15 
minutes at 13,000 rpm. The supernatant was recovered, and DNA was precipitated by the addition of $600 \mu \mathrm{L}$ of $100 \%$ ethanol. The homogenate was placed in the freezer at 30 minutes for 1 hour, then centrifuged at 13000 rpm for 25 minutes, after which the ethanol was discarded and the resulting pellet air dried for 10 minutes. The DNA pellets was re-suspended in $50 \mu \mathrm{L}$ of $0.5 \mathrm{X}$ Tris-EDTA (TE) (pH 8.0). Fivemicroliter $(5 \mu \mathrm{L})$ portions of the DNA extracted were used for PCR amplification.

\subsection{Molecular identification of sand fly}

\subsubsection{The cytochrome c oxidase I (COI) gene}

The cytochrome c oxidase I (COI) gene, widely used for biological barcoding, was targeted in selected samples identified morphologically to species level. The mitochondrial cytochrome c oxidase gene subunit I (COI) was amplified using previously described primers [18]. DNA extracts from individual sand fly were used as template and the primers LCO1490 forward: 5'- GGT CAA ATC ATA AAG ATA TTG G- '3 and HCO2198 reverse: 5'- TAA ACT TCA GGG TGA CCA AAA AAT CA- '3 (Macrogene, Korea) were designed for the amplification of 658bp. The amplification was performed using $0.125 \mu \mathrm{L}$ of One Taq DNA polymerase [1.25 $\mathrm{U} / 50 \mu \mathrm{L}$ ] (New England Biolabs, Inc.) in a total reaction volume of $25 \mu \mathrm{L}$ containing $5 \mu \mathrm{L}$ of DNA, $0.5 \mu \mathrm{L}$ dNTPs (dATP, dCTP, dGTP and dTTP) $[10 \mathrm{mM}], 5 \mu \mathrm{L}$ of buffer (containing 1.8 $\mathrm{mM}$ of $\mathrm{MgCl}$ ) [5X], $0.5 \mu \mathrm{L}$ of each of primer $[10 \mu \mathrm{M}]$, and sterilized water to make up the final volume. The modified thermal cycling conditions previously used by Gutiérrez et al., [19] with slight modifications: an initial denaturation at $95^{\circ} \mathrm{C}$ for 5 min, amplification was performed with 37 cycles consisting of denaturation at $94^{\circ} \mathrm{C}$ for $30 \mathrm{~s}$, annealing at $53^{\circ} \mathrm{C}$ for $45 \mathrm{~s}$, extension at $68^{\circ} \mathrm{C}$ for $1 \mathrm{~min} 30 \mathrm{~s}$, followed by a final extension at $68^{\circ} \mathrm{C}$ for $10 \mathrm{~min}$ and $4{ }^{\circ} \mathrm{C}$ as holding temperature. For each PCR, a negative control containing sterilized distilled water instead of DNA was included. The positive control were previously identified sand flies obtained from the Noguchi Memorial Institute for Medical Research. The reaction was carried out in the BIO RAD System Peltier Thermal Cycler.

\subsubsection{Sequencing and Phylogenetic Analysis}

The PCR amplified products obtained was sequenced by Sanger's method in both forward as well as reverse directions and sequencing results were obtained from Applied Biosystems (ABI): ABI 3500XL Genetic Analyser, POP7TM and Brilliant Dye ${ }^{\mathrm{TM}}$ Terminator v3.1 (NimaGen BV, Nijmegen). The same primers used for the PCR reactions was used. The nucleotide sequences from both strands were aligned using the DNASTAR (Lasergene) software. Sequences was then compared with the GenBank database using NCBI BLASTN (https://blast.ncbi.nlm.nih.gov/Blast.cgi), aligned and analysed in MEGA version 7 . Phylogenetic tree was constructed using the Neighbour Joining (NJ) method.

\section{Results}

\subsection{Morphological identification of sand flies}

Overall, 537 sand flies were collected and 363 $(67.60 \%)$ were morphologically identified as females under the optical microscope and grouped into species using taxonomic keys [5]. Males are not involved in the transmission cycle of the parasite since male sand flies are not blood feeders and were thus excluded from the study. Typically, Phlebotomus species was usually larger bodied with lighter integument whilst Sergentomyia species was smaller with a darker cuticle. In all eleven different species of sand flies were identified (Figure 3). The morphologically identified female sand flies belonged to two genera with $3.31 \%$ belonging to the genus Phlebotomus and $96.69 \%$ to the genus Sergentomyia. The genus Phlebotomus was Phlebotomus rhodaini whilst the genus Sergentomyia included, Sergentomyia africana, Sergentomyia similima, Sergentomyia ghesquierei, Sergentomyia ingrami, Sergentomyia schwetzi, Sergentomyia antennata, Sergentomyia hamoni, Sergentomyia dureini, Sergentomyia buxtoni and Sergentomyia collarti. All these species were captured in the three communities with the exception of Sergentomyia collarti which was captured only at Lume Atsiame. Sergentomyia africana was the most abundance $(26.17 \%)$. 


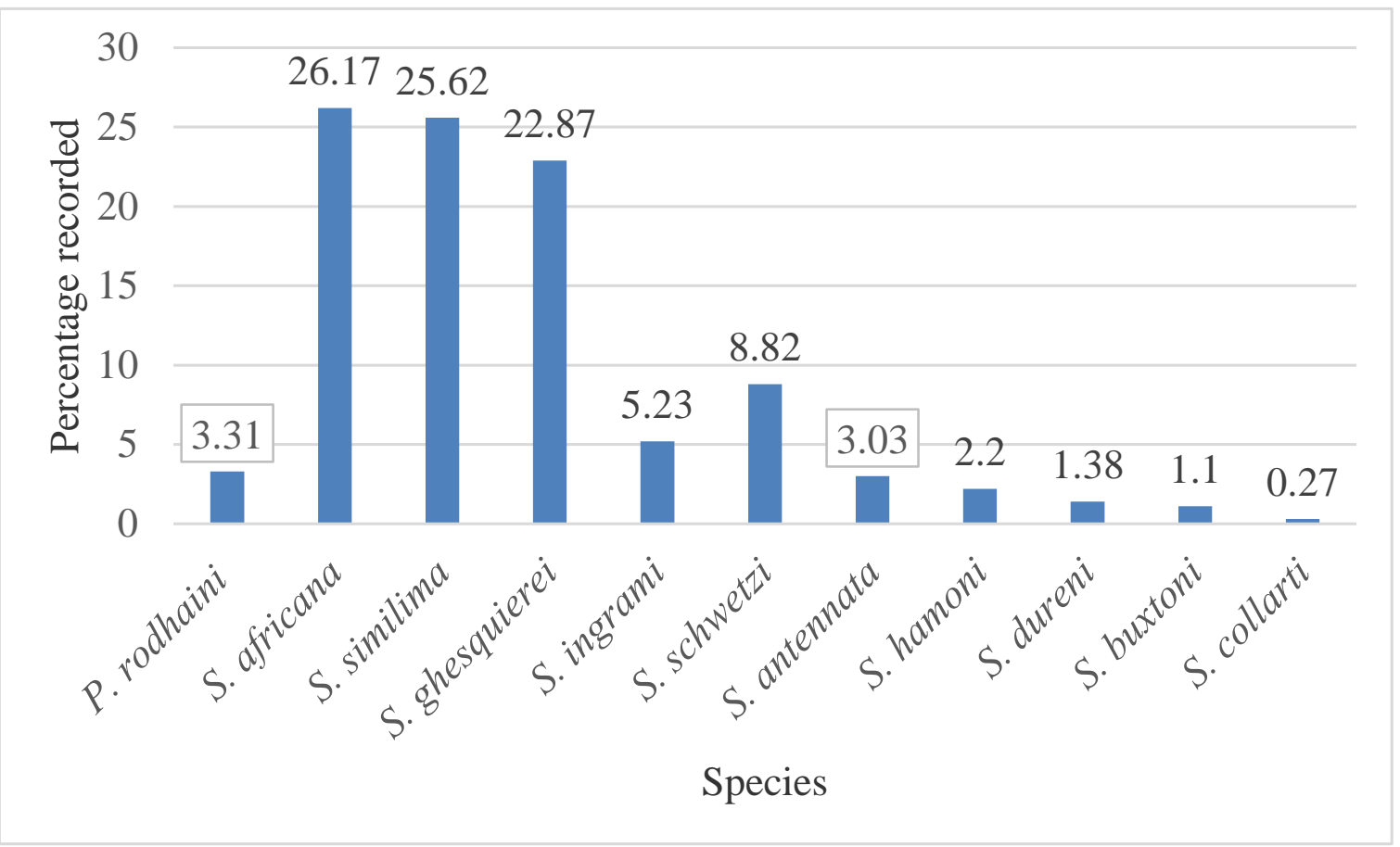

Figure 3: Percentage $(\%)$ of sand flies identified from two genera - Phlebotomus $(P)$ and Sergentomyia $(S)$ in the study area

Table 1: Characteristic features of the collected sand fly species

\begin{tabular}{|c|c|c|c|c|}
\hline \multirow[b]{2}{*}{ No. } & \multirow[b]{2}{*}{ Sandfly species } & \multicolumn{3}{|c|}{ Morphological characteristics } \\
\hline & & Cibarium & Pharynx & Spermathecae \\
\hline 1. & $\begin{array}{l}\text { Phlebotomus } \\
\text { rhodaini }\end{array}$ & lacks rows of teeth & weakly distended & long tubular \\
\hline 2. & $\begin{array}{l}\text { Sergentomyia } \\
\text { africana }\end{array}$ & well-developed set of teeth & hour-glass shaped & double walled \\
\hline 3. & $\begin{array}{l}\text { Sergentomyia } \\
\text { antennata }\end{array}$ & lateral teeth & heart-shaped & long \\
\hline 4. & $\begin{array}{l}\text { Sergentomyia } \\
\text { buxtoni }\end{array}$ & $\begin{array}{l}\text { mushroom shaped cibarium } \\
\text { patch }\end{array}$ & diamond shape & wide tubular \\
\hline 5. & $\begin{array}{l}\text { Sergentomyia } \\
\text { collarti }\end{array}$ & fence-like cibarial teeth & narrow & elongated tubular \\
\hline 6. & $\begin{array}{l}\text { Sergentomyia } \\
\text { dureni }\end{array}$ & median teeth & extended & tubular \\
\hline 7. & $\begin{array}{l}\text { Sergentomyia } \\
\text { ghesquierei }\end{array}$ & $31-40$ teeth & Lamp-glass shaped & tubular \\
\hline 8. & $\begin{array}{l}\text { Sergentomyia } \\
\text { hamoni }\end{array}$ & long, sharp cibarial teeth & Broad-heart shaped & long \\
\hline 9. & $\begin{array}{l}\text { Sergentomyia } \\
\text { ingrami }\end{array}$ & two sets of teeth & narrow shaped & elongated capsule \\
\hline 10. & $\begin{array}{l}\text { Sergentomyia } \\
\text { schwetzi }\end{array}$ & tightly packed median teeth & distended posteriorly & tubular \\
\hline 11. & $\begin{array}{l}\text { Sergentomyia } \\
\text { similima }\end{array}$ & $\begin{array}{l}\text { teeth are equal sized, pointed, } \\
\text { fence-like }\end{array}$ & heart shaped & $\begin{array}{l}\text { tubular spermatheca with } \\
\text { ducts separated at the base }\end{array}$ \\
\hline
\end{tabular}

The CDC light traps captured $94.21 \%$ sand flies whereas the sticky paper traps captured the remaining $5.79 \%$. In all $69.97 \%$ of the sand flies was captured at Dodome Dogblome, 23.69\% at Lume Atsiame and 6.34\% at Dodome Awuiasu.
The characteristic features of the collected sand fly species and images of the morphologically identified sand flies is presented in Table 1 and Figure 4 respectively. 
A

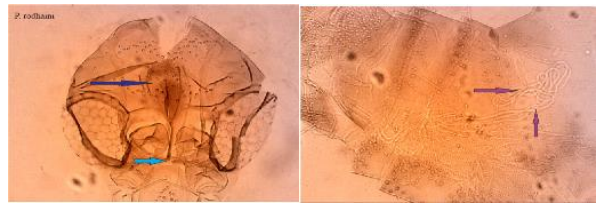

B

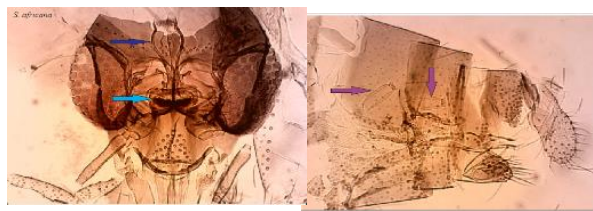

C

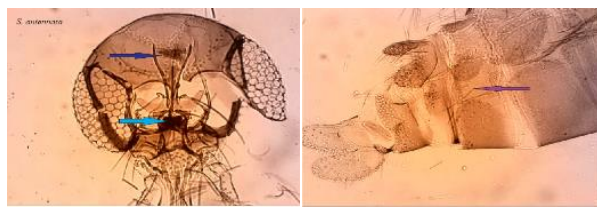

$\mathrm{D}$

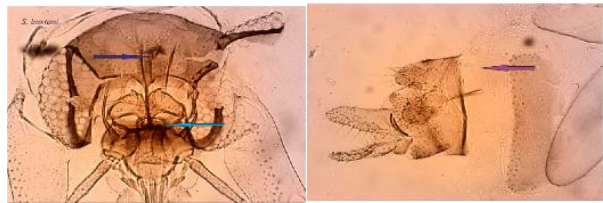

$\mathrm{E}$

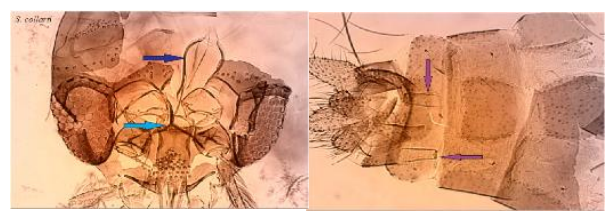

$\mathrm{F}$

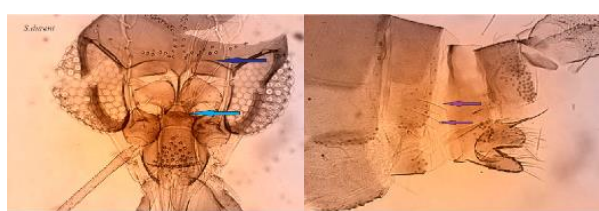

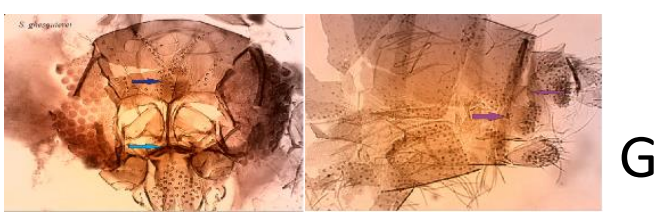
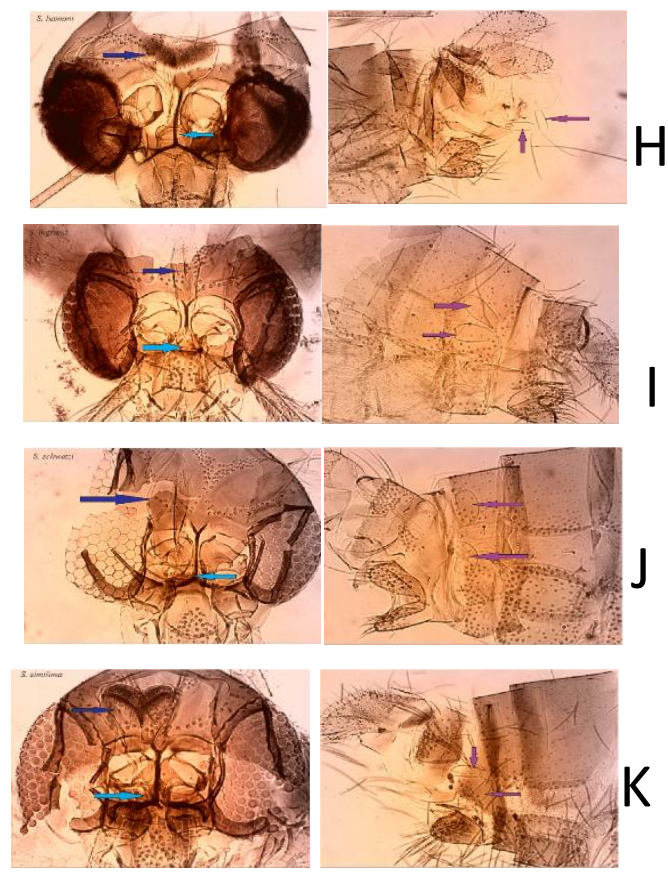

Figure 4: Image of pharynx (blue), cibarium (cyan) and spermathecae (purple) [A]. Phlebotomus rodhaini [B]. Sergentomyia africana [C]. Sergentomyia antennata [D] Sergentomyia buxtoni [E]. Sergentomyia collarti [F]. Sergentomyia dureni [G]. Sergentomyia ghesquierei [H]. Sergentomyia hamoni [I]. Sergentomyia ingrami [J]. Sergentomyia schwetzi and [K]. Sergentomyia similima
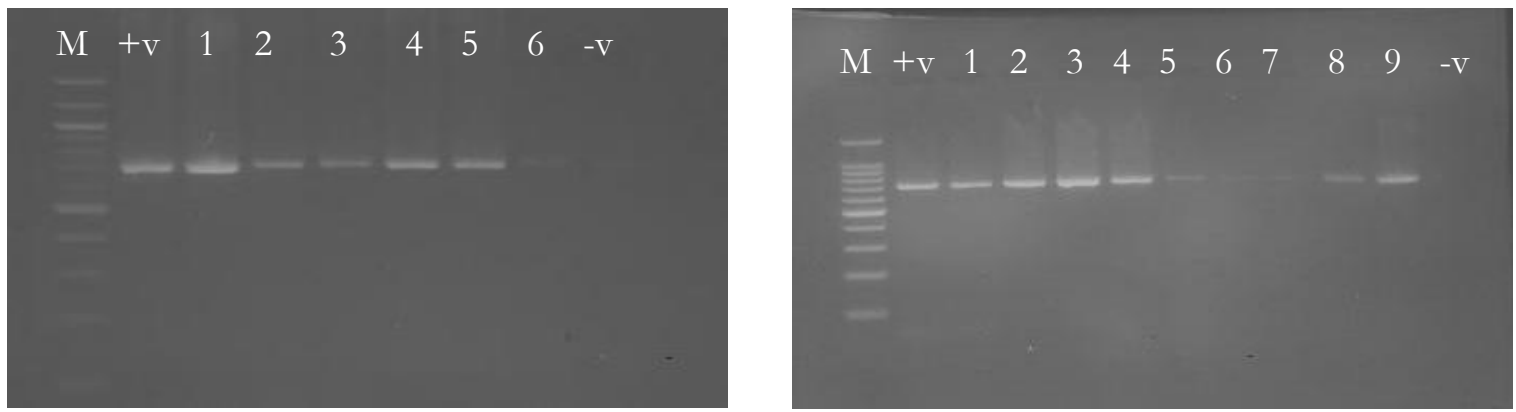

Figure 5: [LEFT] Agarose gel electrophoresis of PCR products of Phlebotomus rodhaini [RIGHT] Sergentomyia similima after amplification of COI gene (658bp). Lane M: Molecular weight marker $(100 \mathrm{bp}) .+v$ (positive control) $-v$ (negative control) 
Edna Dzifa Doe et al., Int. Ann. Sci.; Vol. 10, Issue 1, pp: 33-44, 2021
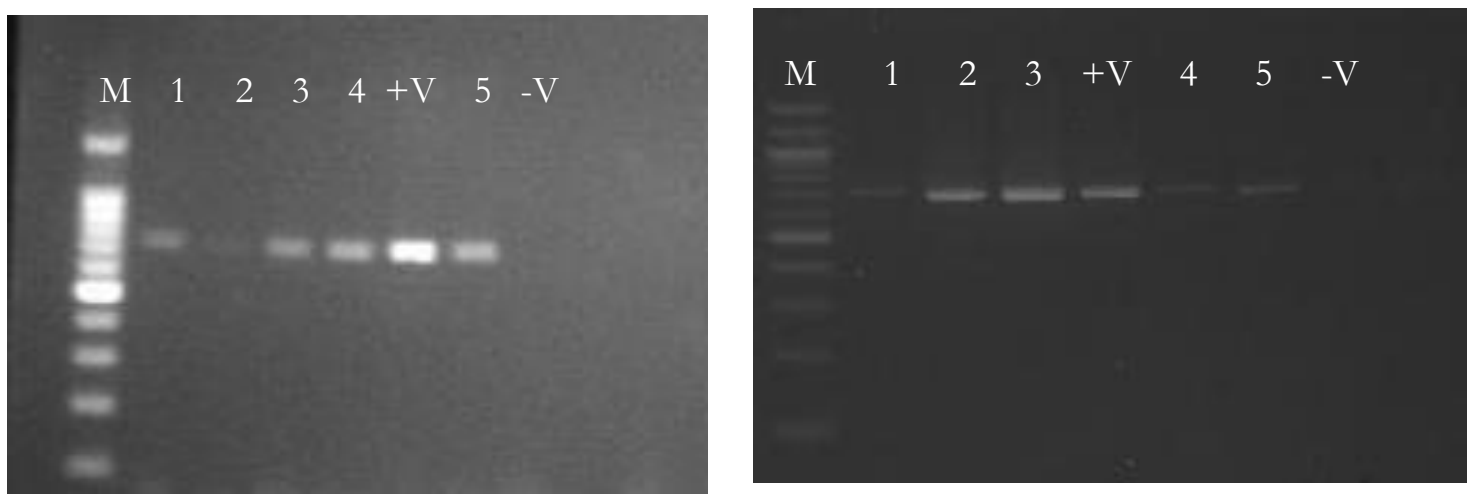

Figure. 6: [LEFT] Agarose gel electrophoresis of PCR products of Sergentomyia antennata [RIGHT] Sergentomyia ingrami after amplification of COI gene (658bp). Lane M: Molecular weight marker $(100 \mathrm{bp}) .+v$ (positive control) $-v$ (negative control)
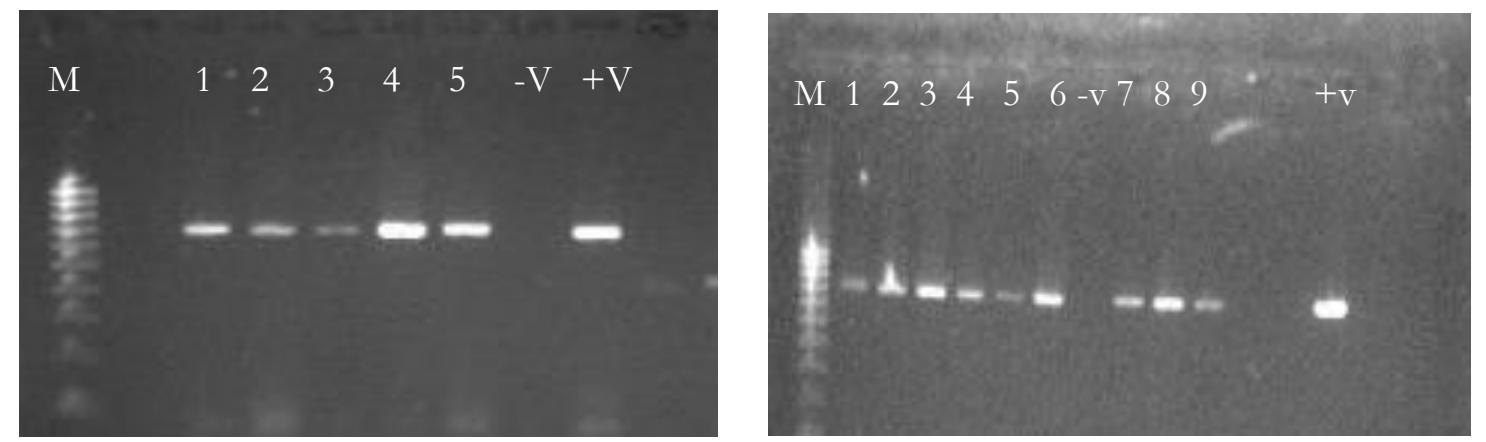

Figure 7: [LEFT] Agarose gel electrophoresis of PCR products of Sergentomyia africana [RIGHT] Sergentomyia ghesquierei after amplification of COI gene (658bp). Lane M: Molecular weight marker (100bp). $+v$ (positive control) $-v$ (negative control)

\subsection{PCR Results}

The validation of the morphologically identified sand fly species was done using mitochondrial cytochrome c oxidase gene subunit I (COI) primers. Polymerase chain reaction (PCR) was performed on the DNA extracts from the individual sand flies. For each of the different species morphologically identified, the PCR amplified products showed bands of molecular weight 658 bp [20] as shown in Figure 5-7.

\subsection{Sequencing Results}

A few randomly selected female sand flies that showed intense agarose gel electrophoresis product was sent for sequencing. However, the COI consensus sequences was obtained only for six species, since most of the sequences either had poor quality or were too short for contig- assembly. However, to ascertain whether the obtained sequenced product was congruent with the morphologically identified sand flies, the obtained sequences was compared with the GenBank database, aligned and analysed in MEGA version 7. The mitochondrial COI sequences obtained varied from 655 to $682 \mathrm{bp}$ by direct sequencing. The sand fly species that yielded good sequence data include: C1 (Phlebotomus rhodaini), C3 (Sergentomyia ghesquierei), C4 (Sergentomyia ingrami), C5 (Phlebotomus rhodaini), C6 (Phlebotomus rhodaini) and C7 (Phlebotomus rhodaini). The neighbour joining method was used to construct the phylogenetic tree (Figure 8). After multiple alignments of study sequences and those obtained from the BLAST and in addition to reference sequences obtained from GenBank the obtained sequence confirmed the morphologically identified sand fly species. 


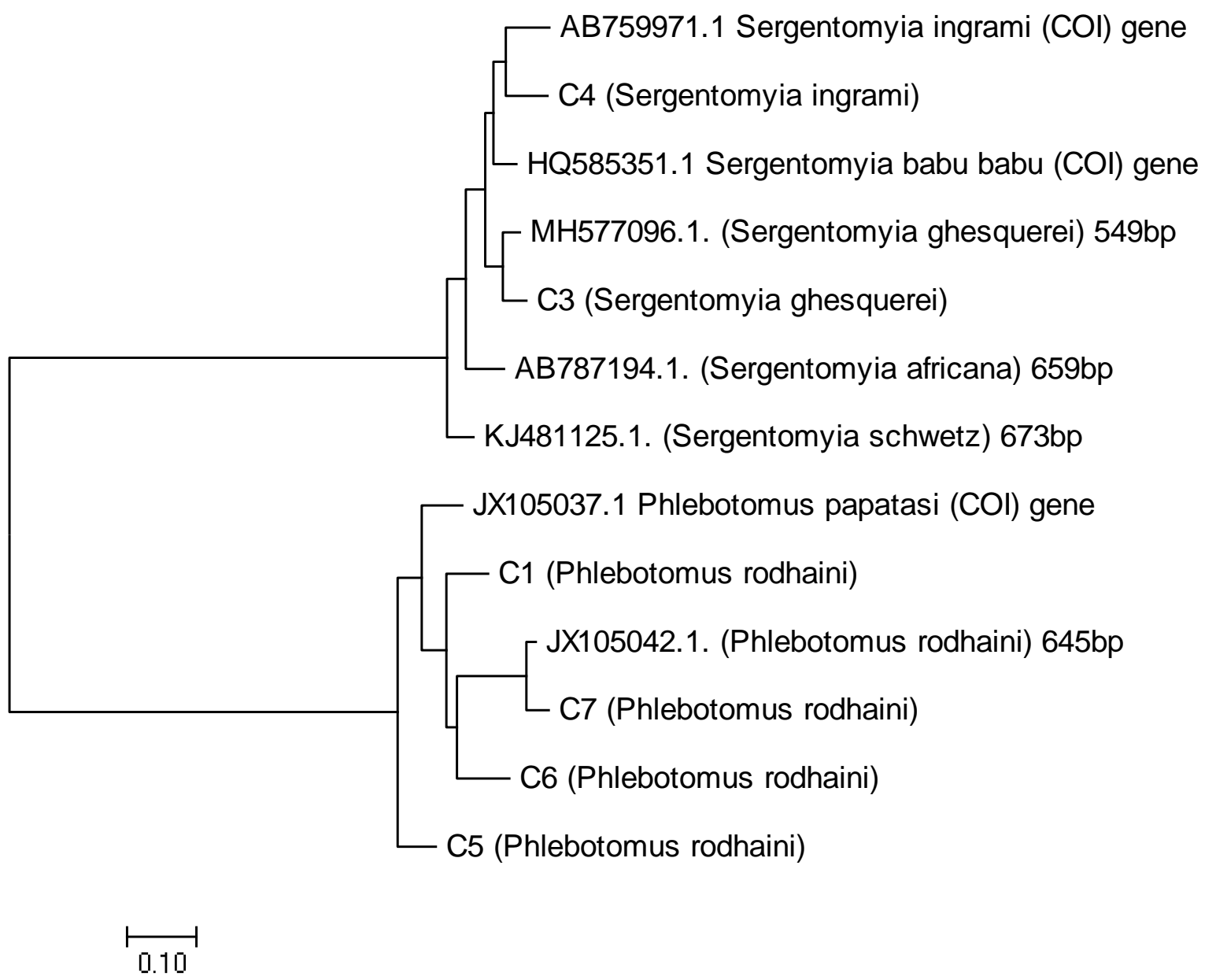

Figure 8: Neighbour Joining tree of different collected sand fly species. AB759971.1, MH577096.1 and JX105042.1 are the reference sequences.

\section{Discussion}

Sand flies, the vectors of leishmaniasis have received considerable attention in recent years, in different parts of the world, due to the discovery of leishmaniasis in some non-endemic areas [21]. Identification of the sand fly is crucial for any leishmaniasis control program [22]. The information generated from the sand flies are of great importance for predicting expansion of the disease in the endemic areas, and further assist in designing new strategic programs that limit spreading of such serious vectors [8].

In this study, 537 sand fly species were captured, $65.64 \%$ representing the females were morphologically identified using taxonomic keys. Since, it is an endemic area the study is expected to capture more females associated with the transmission of the disease. Additionally, 3.31\% of Phlebotomus species and $96.69 \%$ of Sergentomyia species of sand flies was identified in the CL endemic areas of Lume Atsiame, Dodome Dogblome and Dodome Awuiasu. The Sergentomyia species were mainly prevalent and this is consistent with previous studies carried out by [23]-[26],[11] in Ghana. Boakye et al., [23] earlier reported that sand flies collected in 1997 and 2002 from Navrongo in the Upper East Region of Ghana also showed prevalence of Sergentomyia species. Elsewhere in Africa similar research carried out in Algeria [27], Mali [28], [29], Morocco [30] and Sudan [31] also identified species of these two genera. This re-echo emphasized the abundance of Sergentomyia species in the tropics as well as certain leishmaniasis endemic communities compared to Pblebotomus species which are scarce or absent [32], for which reason it's not fully understood [33].

Of the three communities that the traps were set to capture the sand flies, Dodome Dogblome 
Edna Dzifa Doe et al., Int. Ann. Sci.; Vol. 10, Issue 1, pp: 33-44, 2021

recorded the highest capture representing 69.98\% followed by Lume Atsiame (23.69\%). This could be attributed to the many plantain and banana plantation close to the residence in Dodome Dogblome. This could possibly create sufficient moisture and suitable breeding habitats and hiding places in the environment. Thus, buttressing the point that humidity and temperature is an important factor for the development of sand fly [30], [34],[35]. Markle and Makhoul, [36] supports this by explaining in their study that sand flies breed in organic matter such as leaf litter. An observation during the sampling period was that due to the dry weather season mostly in November and December no sand fly was trapped either by the CDC light traps or the sticky paper traps. However, it was observed that the month of May recorded the highest capture of sand flies, this could be attributed to the fact that sand flies are highly prevalent in rainy season and moisted condition [37].

For adequate knowledge of the ecological and medical importance of sand flies in an endemic community, correct identification of the fragile and minute sand fly is paramount. The gold standard for any robust taxonomic system is its ability to deliver reliable and accurate species identification [12]. The morphological identification of sand flies based on various morphological features is quite tedious and timeconsuming and also requires taxonomic expertise [3] It is also difficult to identify large number of sand flies in a short period of time. Therefore, molecular identification is advocated for, which is found to be faster and had the advantage of sensitivity and specificity [38].

In sand fly taxonomy research, identification via COI sequencing is the most used molecular identification method. This is quite popular in the New World and is advancing rapidly in the Old World [39]. The fundamental aim is to standardize molecular approach used in complementing morphological species identification [40], [19]. The study thus utilized the use of COI sequencing as a reliable method to identify the captured sand flies. Kim et al., [41] reported that COI sequencing has been widely used in species identification and biodiversity research because it has been shown that in many groups, including insects, interspecific variation in DNA sequences of some genes is much higher than intraspecific and this provided an opportunity to use DNA sequences for species identification. This, has gained increased recognition as a molecular tool for species identification in various groups of organisms and thus provides a reliable, cost-effective and accessible solution to exact species identification [12]. This approach of identification uses a short sequence from standardized portions of the mitochondrial genome (a 658 bp of COI). It is noteworthy that mitochondrial DNA (mt DNA) is used because it is much smaller than nuclear DNA thus making sequencing it relatively easy [42].

In this study the mitochondrial COI primers was able to molecularly confirm the identity of the sand flies that had been morphologically identified and DNA sequenced. The phylogenetic tree obtained from the neighbour joining method clearly showed that all sequences from the same species cluster together (Figure 8). The mitochondrial COI results agreed with the morphological identification for the species. Besides the remarkable usefulness of COI for species discrimination, it could also be a valuable tool for epidemiologic studies and vectorial control programs, where species identification is the basis of their effectiveness [43].

\section{Conclusion}

This study was carried out to identify sand fly species in an endemic area morphologically and molecularly using the COI primers. It revealed the diversity of sand flies in the endemic area even though the sticky paper traps were not able to intercept a lot of the sand flies as compared to the CDC light traps. The study further reiterated the fact that the Sergentomyia species of sand flies are abundant in Ghana than the Phlebotomus species and majority of the sand fly were collected at Dodome Dogblome. Sergentomyia africana was the most abundant species collected suggesting that its vector competence should be further investigated to ascertain if it plays a role in disease transmission. It can conclusively be said that the molecular identification of sand flies via COI 
sequencing accurately identified these medically important insects thereby assisting traditional morphological identification. This will thus help to assess their implication in Leishmania transmission in an endemic area.

\section{Declarations}

\subsection{Study Limitations}

The study did not receive funding thus all the morphologically identified sand fly species could not be DNA sequenced.

\subsection{Acknowledgements}

The authors acknowledge the Department of Biomedical Sciences, School of Allied Health Sciences of the University of Cape Coast. The services rendered by Mr. Sylvester Nyarko and Dr. Adolf Kofi Awua is gratefully acknowledged.

\subsection{Competing Interests}

The authors declared that no conflict of interest exists.

\section{How to Cite this Article:}

Edna Dzifa Doe et al., "Identification of Sand Flies (Diptera: Psychodidae) Collected from Cutaneous Leishmaniasis Endemic Focus in the Ho Municipality, Ghana”, Int. Ann. Sci., vol. 10, no. 1, pp. 33-44, Sep. 2020. https://doi.org/10.21467/ias.10.1.33-44

\section{References}

[1] S.N. Al-Huchaimi, R.T. Al-Nafakh, Z.A. Al-Khafaji, N. Amad, T.A. Mahmood, S. Bedri, and Y. Bustan, "Phylogenetic analysis of sandflies populations using cytochrome b (mtCytb) gene and identification of Leishmania DNA within infected Sandflies, from the city of Najaf, Iraq, " J Contemp Med Sci., vol. 4, pp. 163169,2018

[2] L.E. Munstermann, "Phlebotomine sand flies, the Psychodidae. In: Biology of disease vectors (eds. J.E. Freier, H.H. Hagedorn, J. Hemingway, S. Higgs, A.A. James, B. Kondratieff and C.G. Moore) (Elsevier, San Diego, CA, USA.,). 2004

[3] E. Dokianakis, N. Tsirigotakis, V. Christodoulou, N. Poulakakis, and M. Antoniou, "Identification of wildcaught phlebotomine sand flies from Crete and Cyprus using DNA barcoding", Parasites \& Vectors, vol. 11, pp. 94, 2018. DOI: 10.1186/s13071-018-2676-0.

[4] U. Sharma, and S. Singh, "Insect vectors for Leishmania: distribution, physiology and their control," Journal of Vector Borne Diseases, vol. 45, pp. 255-272, 2008.

[5] E. Abonnenc, "Sand flies from the Ethiopian region (Diptera, Psychodidae)," Paris ORSTOM memoiirs multigr., 55, 289 ,

1972. http://www.documentation.ird.fr/hor/fdi:05363.
[6] D.G. Young, and M.A. Duncan, "Guide to the Identification and Geographic Distribution of Lutzomyia Sand Flies in Mexico, the West Indies Central and South America (Diptera: Psychodidae). Memoirs of the American Entomological Institute," (Associated Publishers American Entomological Institute, Gainsville, FL.), vol. 54, 1994.

[7] D.J. Lewis, "The phlebotomine sand flies (Diptera, Psychodidae) of the oriental region," Bull. Br. Muse. Natl. His (Entomology), vol. 37, pp. 217-343,1978.

[8] M. Fujita, H. Kato, A.G. Cáceres, E.A. Gomez, T. Mimori, F. Zhang, H. Iwata, M. Korenaga, T. Sakurai, K. Katakura, and Y. Hashiguchi, "Genotyping of sand fly species in Peruvian Andes where leishmaniasis is endemic, "Acta Tropica, vol. 121, pp. 93-98 , 2012. http://hdl.handle.net/2115/48545.

[9] N. Khalid, D. Elnaiem, M. Aboud, F. Al Rabba, and F. Tripet, "Morphometric and molecular differentiation of Phlebotomus (Phlebotomus) sandflies," Medical and Veterinary Entomology, vol. 24, pp. 352-360, 2010. DOI: $\quad$ http://doi.wiley.com/10.1111/j.13652915.2010.00893.x.

[10] J. Mukhopadhyay, K. Ghosh, and H.R. Braig, "Identification of cutaneous Leishmaniasis vectors, Phlebotomus papatasi and $\mathrm{P}$. duboscqi using random amplified polymorphic DNA," Acta Tropica, vol. 76, pp. 277-283, 2000.

[11] C.O. Nzelu, H. Kato, N. Puplampu, K. Desewu, S. Odoom, M.D. Wilson, T. Sakurai, K. Katakura, and D.A. Boakye, "First Detection of Leishmania tropica DNA and Trypanosoma Species in Sergentomyia Sand Flies (Diptera: Psychodidae) from an Outbreak Area of Cutaneous Leishmaniasis in Ghana PLoS Neglected Tropical Diseases, vol. 8, e2630, 2014. http://dx.plos.org/10.1371/journal.pntd.0002630

[12] P.D.N. Hebert, A. Cywinska, S.L. Ball, and J.R. deWaard, "Biological identifications through DNA barcodes," Proceedings of the Royal Society of London. Series B: Biological Sciences, vol. 270, pp. 313-321,2003. http://www.royalsocietypublishing.org/doi/10.1098/rsp b.2002.2218.

[13] R.A. Al-Ajmi, "Individual Variations in Phlebotomus papatasi Collected from Different Localities in Saudi Arabia,', Egypt. Acad. J. Biolog. Sci., vol. 6, pp.79-88, 2013.

[14] Ghana Statistical Services. Ghana Statistical Services Report. 2014. http://www2.statsghana.gov.gh/docfiles/2010_District_ Report/Volta/HO\%20MUNICIPAL.pdf.

[15] Directorate of Health Services. Directorate of Health Services, Ho, 2016. https://www.ghanahealthservice.org/downloads/GHS_A NNUAL_REPORT_2016_n.pdf

[16] G. Kwakye-Nuako, M.-T. Mosore, C. Duplessis, M.D. Bates, N. Puplampu, I. Mensah-Attipoe, K. Desewu, G. Afegbe, R.H. Asmah, M.B. Jamjoom, P.F. Ayeh-Kumi, D.A. Boakye, and P.A. Bates, "First isolation of a new species of Leishmania responsible for human cutaneous leishmaniasis in Ghana and classification in the Leishmania enriettii complex, "International Journal for Parasitology, vol. 45, pp. 679-684,2015. http://dx.doi.org/10.1016/j.ijpara.2015.05.001.

[17] A.M. Aransay, E. Scoulica, and Y. Tselentis, "Detection and Identification of Leishmania DNA within Naturally Infected Sand Flies by Seminested PCR on Minicircle 
Edna Dzifa Doe et al., Int. Ann. Sci.; Vol. 10, Issue 1, pp: 33-44, 2021

Kinetoplastic DNA," Applied and Environmental Microbiology, vol. 66, pp. 1933-193,2000.

[18] O. Folmer, M. Black, W. Hoeh, R. Lutz, and R. Vrijenhoek, "DNA primers for amplification of mitochondrial cytochrome c oxidase subunit I from diverse metazoan invertebrates," Molecular Marine Biology and Biotechnology, vol. 3, pp. 294-299, 1994.

[19] M.A.C. Gutiérrez, R.J. Vivero, I.D. Vélez, C.H. Porter, and S. Uribe, "DNA Barcoding for the Identification of Sand Fly Species (Diptera, Psychodidae, Phlebotominae) in Colombia," PLOS ONE, vol. 9, e85496,2014. DOI: 10.1371/journal.pone.0085496.

[20] E.C da S. Chagas, A.S. Silva, N.F. Fé, L.S. Ferreira, V. de S. Sampaio, W.C.M. Terrazas, J.A.O. Guerra, RA.F. de Souza, H. Silveira and M. das G.V.B Guerra, "Composition of sand fly fauna (Diptera: Psychodidae) and detection of Leishmania DNA (Kinetoplastida: Trypanosomatidae) in different ecotopes from a rural settlement in the central Amazon, Brazil, " Parasites \& Vectors, 11, 180, 2018. https://doi.org/10.1186/s13071018-2743-6.

[21] B. Alemayehu, and M. Alemayehu, "Leishmaniasis: A Review on Parasite, Vector and Reservoir Host," Health Science Journal, vol. 11, 2017. DOI: 10.21767/1791809X.1000519.

[22] A. Baharshahi, M. Behravan, and A. keykhosravi, "Morphological Identification of Sandflies and Their Species' Diversity," Journal of Paramedical Sciences (JPS), vol. 9, 2016.

[23] D.A. Boakye, M.D. Wilson, and M. Kweku, "A Review of Leishmaniasis in West Africa," Ghana Medical Journal, vol. 39, pp. 94-97, 2005.

[24] D.J. Fryauff, H. A. Hanafi, J. D. Klena, D. F. Hoel, M. Appawu, W. Rogers, N. Puplampu, S. Odoom, M. Kweku, K. Koram, M. D. Wilson, G. Raczniak, and D. Boakye, "Short Report: ITS-1 DNA Sequence Confirmation of Leishmania major as a cause of cutaneous leishmaniasis from an outbreak focus in the Ho District, South Eastern Ghana, " Am. J. Trop. Med. Hyg., vol. 75, pp. 502-504, 2006.

[25] M.A. Kweku, S. Odoom, N. Puplampu, K. Desewu, G.K. Nuako, B. Gyan, G. Raczniak, K.C. Kronmann, K. Koram, S. Botero, D. Boakye, and H. Akuffo, "An outbreak of suspected cutaneous leishmaniasis in Ghana: lessons learnt and preparation for future outbreaks, ", Global Health Action, vol. 4, pp. 5527, 2011. DOI: 10.3402/gha. v4i0.5527.

[26] M.-T. Mosore, "Leishmania infection in sand flies in a Cutaneous Leishmaniasis focus in Ghana," Master of Phylosophy. Kwame Nkrumah University of Science and Technology, 2016. http://dspace.knust.edu.gh:8080/jspui/handle/12345678 9/878.

[27] K. Bennai, D. Tahir, I. Lafri, A. Bendjaballah-Laliam, I. Bitam, and P. Parola, "Molecular detection of Leishmania infantum DNA and host blood meal identification in Phlebotomus in a hypoendemic focus of human leishmaniasis in northern Algeria," $P L O S$ Neglected Tropical Diseases, vol. 12, e0006513,2018. https://dx.plos.org/10.1371/journal.pntd.0006513.

[28] Z. Berdjane-Brouk, A.K. Koné, A.A. Djimdé, R.N. Charrel, C. Ravel, P. Delaunay, P. del Giudice, A.Z. Diarra, S. Doumbo, S. Goita, M.A. Thera, J. Depaquit, P. Marty, O.K. Doumbo, and A. Izri, "First Detection of Leishmania major DNA in Sergentomyia (Spelaeomyia) darlingi from Cutaneous Leishmaniasis Foci in Mali, ,
PLoS ONE, vol. 7, e28266, 2012. DOI: 10.1371/journal.pone.0028266.

[29] C.A Coulibaly, I. Sissoko, B. Traore, A. Diallo, S. Samake, S.F. Traore, and S. Doumbia, "Diversity of Sand Flies (Diptera: Psychodidae: Phlebotominae) in Two Different Eco-Climatic and Endemic Zones of Cutaneous Leishmaniasis in Mali, West Africa," Journal of Medical Entomology, vol. 53, pp. 923-927, 2016. DOI: 10.1093/jme/tjw060.

[30] M. Ajaoud, N. Es-sette, S. Hamdi, A. El-Idrissi, M. Riyad, and M. Lemrani, M, "Detection and molecular typing of Leishmania tropica from Phlebotomus sergenti and lesions of cutaneous leishmaniasis in an emerging focus of Morocco," Parasites \& Vectors, vol. 6, pp. 217, 2013. DOI: $10.1186 / 1756-3305-6-217$.

[31] B.A. A. Adam, M.M. Hassan, O.M. Abdelnour, and A.H. Awadallah, "Identification and Classification of Sand Flies Species and It's Habitats in El-Kadaba Village, White Nile State, Sudan" International Journal of Infectious Diseases and Therapy, vol. 2, pp. 15-21, 2017. DOI: 10.11648/j.ijidt.20170201.14.

[32] M. Akhoundi, K. Kuhls, A. Cannet, J. Votýpka, P. Marty, P. Delaunay and D. Sereno, "A Historical Overview of the Classification, Evolution, and Dispersion of Leishmania Parasites and Sandflies," PLOS Neglected Tropical Diseases, vol. 10, e0004349, 2016. DOI: 10.1016/j.mam.2016.11.012.

[33] C. Maia, and J. Depaquit, "Can Sergentomyia (Diptera, Psychodidae) play a role in the transmission of mammalinfecting Leishmania?'” Parasite, vol. 23, pp. 55, 2016. DOI: 10.1016/j.tvjl.2007.08.009.

[34] O.E Kasap, and B. Alten, "Comparative demography of the sand fly Phlebotomus papatasi (Diptera: Psychodidae) at constant temperatures," Journal of Vector Ecology: Journal of the Society for Vector Ecology, vol. 31, pp. 378-385,2006. DOI: 10.3376/1081-1710(2006)31 [378: cdotsf]2.0.co;2.

[35] M. Service, M. "Phlebotomine sand-flies. In: Service M, Editor. Medical Entomology for Students," (Cambridge: Cambridge University Press).2008. parasitesandvectors.biomedcentral.com/articles/10.118 6/1756-3305-1-12.

[36] W. Markle, and K. Makhoul, "Cutaneous Leishmaniasis Recognition and Treatment," American Family Physician, vol. 69, pp. 1455-1460, 2004.

[37] P. Tiwary, D. Kumar, M. Mishra, R.P. Singh, M, Rai, and S. Sundar, "Seasonal Variation in the Prevalence of Sand Flies Infected with Leishmania donovani,"' PLOS ONE, vol. $\quad 8, \quad$ e61370, 2013. DOI: 10.1371/journal.pone.0061370.

[38] C.O Nzelu, A.G. Cáceres, M.J. Arrunátegui-Jiménez, M.F. Lañas-Rosas, H.H. Yañez-Trujillano, D.V. Luna-Caipo, C.E. Holguín-Mauricci, K. Katakura, Y. Hashiguchi, and H. Kato, "DNA barcoding for identification of sand fly species (Diptera: Psychodidae) from leishmaniasisendemic areas of Peru, "'Acta Tropica, vol. 145, pp. 4551,2015 . http://dx.doi.org/10.1016/j.actatropica.2015.02.003.

[39] J. Depaquit, "Molecular systematics applied to Phlebotomine sandflies: Review and perspectives," Infection, Genetics and Evolution, vol. 28, pp. 744-756, 2014. https://doi.org/10.1016/j.meegid.2014.10.027.

[40] J. Azpurua, D. De La Cruz, A. Valderama, and D.Windsor, "Lutzomyia Sand Fly Diversity and Rates of Infection by Wolbachia and an Exotic Leishmania Species on Barro Colorado Island, Panama, " PLoS Neglected Tropical 
Identification of Sand Flies (Diptera: Psychodidae) Collected from Cutaneous Leishmaniasis Endemic Focus in the Ho Municipality, Ghana

Diseases, vol. 4, e627, 2010. DOI: 10.1371/journal.pntd.0000627.

[41] D. W. Kim, W.G. Yoo, H.C. Park, H.S. Yoo, D.W. Kang, S.D. Jin,, H.K. Min, W.K. Paek, and J. Lim, "DNA Barcoding of Fish, Insects, and Shellfish in Korea, , Genomics \& Informatics, vol.10, pp. 206,2012. DOI: 10.5808/GI.2012.10.3.206

[42] J. Rivera, and D.C. Currie, "Identification of Nearctic black flies using DNA barcodes (Diptera: Simuliidae), , Molecular Ecology Resources, vol. 9, pp. 224-236, 2009. DOI: 10.1111/j.1755-0998.2009. 02648.x.

[43] R. Lozano, M. Naghavi, K. Foreman, S. Lim, K. Shibuya, V. Aboyans, J. Abraham, T. Adair, R. Aggarwal, S.Y. Ahn, M.A. AlMazroa, M. Alvarado, H.R. Anderson, L.M. Anderson, K.G.Andrews, C. Atkinson, L.M. Baddour, S. Barker-Collo, D.H. Bartels, M.L. Bell, "Global and regional mortality from 235 causes of death for 20 age groups in 1990 and 2010: a systematic analysis for the Global Burden of Disease Study 2010, ' The Lancet, vol. 380 , pp. 2095-2128, 2012. DOI: 10.1016/S01406736(12)61728-0.
Publish your research article in AIJR journals-

$\checkmark \quad$ Online Submission and Tracking

$\checkmark \quad$ Peer-Reviewed

$\checkmark \quad$ Rapid decision

$\checkmark \quad$ Immediate Publication after acceptance

$\checkmark \quad$ Articles freely available online

Retain full copyright of your article.

Submit your article at journals.aijr.in

Publish your books with AIJR publisher-

$\checkmark \quad$ Publish with ISBN and DOI.

$\checkmark \quad$ Publish Thesis/Dissertation as Monograph.

$\checkmark \quad$ Publish Book Monograph.

$\checkmark$ Publish Edited Volume/ Book.

$\checkmark \quad$ Publish Conference Proceedings

$\checkmark \quad$ Retain full copyright of your books.

Submit your manuscript at books.aijr.org 